\title{
MEMBANGUN HUKUM PIDANA NASIONAL DI ATAS PONDASI KEADILAN PANCASILA DALAM WUJUD NILAI KE TUHANAN YANG MAHA ESA
}

\author{
Nanda Sahputra Umara ${ }^{1}$ dan Pathorang Halim² \\ Nandasahputra94@gmail.com/ pathoranghalim@gmail.com \\ Program Doktor Ilmu Hukum Fakultas hukum UNDIP dan \\ Fakultas Hukum Universitas Krisnadwipayana.
}

\begin{abstract}
Abstrak
Ketertinggalan hukum pidana di Indonesia, berimplikasi pada penegakan hukum yang cenderung kurang adil dan tidak beradab. Karakter KUHP yang yang masih digunakan sampai saat ini didasarkan pada pandangan yang legalistic, karenanya sudah tidak cocok lagi dan jauh dari harapan cita-cita hukum nasional yang yang diharapkan. Pemberlakuan KUHP di indonesia tidak lepas dari napak tilas hukum belanda yang karakteristiknya jauh dari nilai kemanusian dan nilai ketuhanan. Karenanya perlu dilakukan pembangunan hukum pidana nasional diatas pondasi pancasila yang dilandasi pada nilai kemanusiaan dan keadilan berdasarkan Ketuhanan yang Maha Esa.
\end{abstract}

Kata Kunci: Sistem Hukum Pidana Nasional, Keadilan Pancasila, Nilai Ketuhanan.

1 Mahasiswa Program Doktor Ilmu Hukum Fakultas Hukum Universitas Diponegoro.

2 Mahasiswa Program Doktor Ilmu Hukum Fakultas Hukum Universitas Krisnadwipayana. 


\title{
172 \\ AL-QISTH LAW REVIEW \\ VOL 5 NO. 1 (2021)
}

\begin{abstract}
The underdevelopment of criminal law in Indonesia has implications for law enforcement which tends to be unfair and uncivilized. The character of the Criminal Code which is still in use today is based on a legalistic wiew, therefore it is no longer suitable and far from the expectations of the expected ideas of nation law. The enactment of the Criminal Code in Indonesia cannot be separated from the traces of Dutch law whose characteristics are far from human values and divine values. Therefore, it is necessary to develop a national criminal law on the foundation of Pancasila which is based on human values and justice based on the One Godhead.
\end{abstract}

Keywords: National Criminal Law System, Pancasila Justice, and DivinityValues

\section{A. PENDAHULUAN}

Diawali dengan pandangan Arief Hidayat yang menyatakan bahwa Diskursus mengenai konsepsi negara hukum Pancasila telah lama menjadi wacana dalam berbagai forum akademis dan ilmiah yang tak kunjung usai dibicarakan dan diperdebatkan. Semuanya sepakat bahwa konsepsi negara hukum Indonesia berbeda dengan konsepsi rechtsstaat maupun rule of law. Konsepsi negara hukum Indonesia memiliki ciri dan karakteristik yang didasarkan pada semangat dan jiwa bangsa (volkgeist) Indonesia, yakni Pancasila. (Hidayat) 


\section{AL-QISTH LAW REVIEW \\ VOL 5 NO. 1 (2021)}

Pancasila sebagai staatsfundamentalnorm bangsa Indonesia, menjadi sebuah sumber pedoman dasar bagi seluruh aspek berkehidupan di Indonesia, termasuk sebagai sumber dari segala sumber hukum, baik dalam hal pembentukan hukum dan penegakan hukum. Pancasila dilihat sebagai cita hukum (rechtsidee) merupakan bintang pemandu. Posisi ini mengharuskan pembentukan hukum positif adalah untuk mencapai ide-ide dalam Pancasila, serta dapat digunakan untuk menguji hukum positif yang tidak seirama dengan nilai-nilai Pancasila itu sendiri. Dengan ditetapkannya Pancasila sebagai staatsfundamentalnorm maka pembentukan hukum, penerapan, dan pelaksanannya tidak dapat dilepaskan dari nilainilai Pancasila. "Penempatan Pancasila sebagai staatsfundamentalnorm pertama kali disampaikan oleh Notonagoro." (Assihiddiqie: 2006.)

Dapat dilihat dalam Pembukaan Undang-Undang Dasar 1945 Alinea IV yang secara jelas menyatakan bahwa Pancasila merupakan norma dasar atau fundamental Negara Kesatuan Republik Indonesia. Kosekuensi logis Pancasila sebagai yang menjiwai setiap norma dalam Peraturan PerundangUndangan, karenanya tiap-tiap pembentukan hukum harus didasarkan pada nilai-nilai Pancasila dan implementasi norma dalam penegakan hukum harus berorientasi pada keadilan berdasarkan Pancasila.

Salah satu tujuan hukum dalam penerapannya pada dasarnya adalah sebagai penegakan keadilan, bahwa tiap-tiap penegakan hukum bukan semata hanya dilihat sebagai serangkaian proses hukum yang harus di tegakan, melalui sudut pandang yang lebih luas bahwa tujuan pengakan 


\section{AL-QISTH LAW REVIEW \\ VOL 5 NO. 1 (2021)}

hukum merupakan penegakan keadilan, dimana nilai-nilai keadilan harus melekat dalam suatu putusan hukum.

Indonesia sebagai negara yang berlandaskan hukum sebagaimana termaktum dalam Pasal 1 ayat (3) Undang-Undang Dasar Negara Republik Indonesia Tahun 1945 (UUD NRI 1945), karenanya membangun negara hukum yang berkeadilan bagi Negara Indonesia merupakan amanah konstitusi, melalui kekuasaan kehakiman yang merdeka dengan lembaga peradilan maka dikehendaki penegakan hukum harus ditegakan berdasarkan keadilan.

Lebih mengkerucut pembahasan dalam tulisan ini pada penegakan hukum pidana, yang selama ini masih didasarkan pada Kitab undangundang hukum pidana disingkat (KUHP). Pemberlakuan KUHP di indonesia tidak lepas dari napak tilas hukum belanda yang didasarkan pada asas konkordansi dimana hukum yang berlaku di negara penjajah berlaku pula di negara jajahannya. Artinya penegakan hukum pidana di Indonesia masih dijiwai suatu substansi norma yang jauh dari nilai-nilai Pancasila sebagai staatsfundamentalnorm bangsa Indonesia. Karakter KUHP yang didasarkan pada pandangan yang legalistik, karenanya sudah tidak cocok lagi dan jauh dari harapan cita-cita hukum nasional yang yang diharapkan pada titik nilai keadilan Pancasila.

Khusus pembangunan terhadap aspek substansi/materi hukum antara lain adalah kajian terhadap perangkat hukum nasional yang ada. Jika melihat perundang-undangan yang ada sekarang terutama hukum pidana 


\section{AL-QISTH LAW REVIEW \\ VOL 5 NO. 1 (2021)}

materiel (substantif) yang berlaku di negeri kita, sampai saat ini masih tetap menggunakan Wetboek van Strafrecht (WvS) atau disebut Kitab Undangundang Hukum Pidana (KUHP) yang merupakan peninggalan pemerintah zaman kolonial Belanda, yang termasuk keluarga/sistem hukum kontinental ("Civil Law System") dan dipengaruhi oleh ajaran yang menonjolkan paham 'individualisme' dan 'liberalisme'. (Wahyuningsih: 2014)

Menurut Satjipto Raharjo pikiran liberal berpusat pada kemerdekaan individu dengan menata suatu kehidupan bahwa kemerdekaan individu tersebut di jamin keberadaan dan kelanjutan keberadaan tersebut. Nilai liberal, kemerdekaan individu, menjadi paradigma dalam sistem hukum. Hal tersebut di atas memberikan implikasi terhadap pemikiran hukum. (Rahardjo: 2001)

Lebih lanjut Arief Hidayat menyatakan: Sebagai sebuah konstruksi politik baru yang bersifat artifisial, negara modern yang baru muncul pada Abad ke-18 di Eropa merupakan sebuah institusi politik yang diciptakan dengan sengaja dan secara rasional, tumbuh menjadi sebuah kekuasaan politik yang dominan, hegemonik, mengintervensi, menggerakkan masyarakat dan menumbangkan tatanan sosial politik yang telah ada sebelumnya. (Hidayat). KUHP sebagai produk negara eroupa memiliki karakteristik yang demikian sama, karenanya bertolak belakang dengan budaya bangsa indonesia. 


\section{AL-QISTH LAW REVIEW \\ VOL 5 NO. 1 (2021)}

Berpangkal tolak dari hukum pidana saat ini yang telah banyak ketertinggalan dan dipengaruhi karakter pikiran liberal, individualistis, melekat asas tiada map bagimu (tidak memberikan pemaafan), karenanya menarik untuk telaah, dalam rangka mengimplementasikan Pancasila dalam pembaruan hukum pidana materiel Indonesia, untuk di kaji urgensi pembaruan hukum pidana materiel Indonesia yang didasarkan pada pendekatan nilai-nilai Ketuhanan Yang Maha Esa sebagai salah satu nilai yang perinsip didalam Pancasila.

\section{B. PEMBAHASAN}

\section{a. Pancasila Sebagai Pondasi Pembangunan Hukum Di Indonesia.}

Pancasila sebagai landasan pembangunan hukum di Indonesia dipelopori oleh Notonagoro. Menurutnya Pancasila memiliki arti penting terhadap pembentukan hukum, Pancasila sebagai falsafah kehidupan bangsa Indonesia merupakan realitas keotentisitasan hukum Indonesia. Menurut beliau, Pancasila secara yuridis telah disepakati sebagai ideologi negara Indonesia, hal tersebut berarti juga membawa implikasi terhadap hukum yang berlaku di Indonesia juga harus berideologi Pancasila. (Nugroho: 2016)

Pembangunan hukum berbasis Pancasila juga disampaikan oleh Sudjito bahwa negara Indonesia dalam menuju peradaban masyarakat bermartabat dihadapkan pada berbagai tantangan dan pengaruh ideologi asing yang mengganggu pencapaian kebijakan yang ditetapkan 


\section{AL-QISTH LAW REVIEW \\ VOL 5 NO. 1 (2021)}

negara.Pancasila sebagai daras filsafat dapat menjadi landasan pembaharuan hukum Indonesia karena memuat nilai-nilai kehidupan masyarakat. Pancasila sebagai ideologi negara berarti ideologi hukum tersebut mengantarkan kristalisasi pola pikir dan sikap serta perilaku kita berdasarkan Pancasila. Pancasila merupakan norma hukum pokok atau kaidah fundamental dan memiliki kedudukan yang tetap dan kuat. Karena Pancasila sebagai ideologi negara Indoenesia, maka Pancasila memiliki pengaruh cukup besar dalam menentukan arah tujuan negara. Sedangkan arah tujuan negara merupakan aturan hukum yang harus ditaati oleh semuanya agar tujuan negara yang akan dicapai dapat terwujud. Dalam rangka itulah Pancasila menjadi sumber pokok segala hukum di Indonesia. (Sudjito: 2014)

Apabila kita melihat secara historis sejak disahkan secara konstitusional pada tanggal 18 Agustus 1945, Pancasila dapat dikatakan sebagai dasar (falsafah) Negara, pandangan hidup, ideologi nasional dan ligature (pemersatu) dalam perikehidupan kebangsaan dan kenegaraan Indonesia. Dengan singkat kata Pancasila adalah dasar statis yang mepersatukan sekaligus bintang penuntun (Leitstar) yang dinamis yang mengarahkan bangsa dalam mencapai tujuannya. Dalam posisi seperti itu, Pancasila merupakan jati diri, kepribadian, moralitas dan haluan keselamatan bangsa. Dengan demikian Negara Indonesia memiliki landasan moralitas dan haluan yang jelas dan visioner. Suatu pangkal tolak dan tujuan pengharapan yang penting bagi keberlangsungan dan kejayaan Negara. (Latif: 2012) 


\section{AL-QISTH LAW REVIEW \\ VOL 5 NO. 1 (2021)}

Pancasila sebagai dasar filsafat dan paradigma pembangunan hukum Indonesia harus menempatkan pancasila sebagai sumber pembentukan, pelaksanaan dan penegakkan hukum. Sehingga Pancasila sebagai ideologi hukum tidak hanya dipandang sebagai syarat formal tertulis saja, tetapi lebih bermakna dan nyata dilaksanakan dalam praktek penegakkan hukum di Indonesia. (Sudjito: 2014). Pancasila merupakan sumber hukum yang tak terhingga luas, dalam dan kayanya. Pancasila merupakan intisari dari segala kelembagaan kenegaraan dan hukum serta penyelesai terhadap masalah-masalah bangsa. Ketatanegaraan Indonesia dengan seluk-beluk pelaksanaan dan permasalahan yang ada dapat terurai dengan menggunakan Pancasila sebagai pedoman pelaksanaannya. Telah terbukti dalam sejarah negara Indonesia bahwa Pancasila menjadi pelindung dari segala ancaman yang berusaha mengganggu integrasi nasional Indonesia. (Nugroho: 2010). Pancasila sebagai falsafah pandangan hidup bangsa seyogyanya dicerminkan dalam prinsip, nilai dan norma kehidupan dalam berbangsa, bernegara dan berbudaya. Dengan demikian nilai-nilai yang melekat pada Pancasila layak menjadi norma dasar bagi tata hukum Indonesia. Dalam konteks itu pancasila merupakan keyakinan normatif Indonesia.

Sebabagai basis moralitas dan haluan kebangsaan-kenegaraan Pancasila memiliki landasan ontologis, epistemologis dan aksiologis yang kuat. Setiap sila memiliki justifikasi historisitas, rasionalitas dan aktualitasnya yang dipahami, dihayati, dipercayaidan diamalkan secara 


\section{AL-QISTH LAW REVIEW \\ VOL 5 NO. 1 (2021)}

konsisten menopang pencapaian agung peradaban bangsa dan dapat mendekatai perwujudan Negara Paripurna.

Menurut Arief Hidayat konsep yang dianut oleh 'negara hukum Indonesia' sejak zaman kemerdekaan hingga saat ini bukanlah konsep Rechtsstaat dan bukan pula konsep the Rule of Law, melainkan membentuk suatu konsep negara hukum baru yang bersumber pada pandangan dan falsafah hidup luhur bangsa Indonesia. Konsep baru tersebut adalah negara hukum Pancasila sebagai kristalisasi pandangan dan falsafah hidup yang sarat dengan nilai-nilai etika dan moral yang luhur bangsa Indonesia, sebagaimana tercantum dalam Pembukaan UUD 1945 dan tersirat di dalam Pasal-pasal UUD NRI Tahun 1945. Dapat dipahami bahwa Pancasila merupakan norma dasar negara Indonesia (grundnorm) dan juga merupakan cita hukum negara Indonesia (rechtsidee) sebagai kerangka keyakinan (belief framework) yang bersifat normatif dan konstitutif. Bersifat normatif karena berfungsi sebagai pangkal dan prasyarat ideal yang mendasari setiap hukum positif, dan bersifat konstitutif karena mengarahkan hukum pada tujuan yang hendak dicapai. Pada tahap selanjutnya Pancasila menjadi pokok kaidah fundamental negara "staatsfundamentalnorm" dengan dicantumkan dalam Pembukaan UndangUndang Dasar Tahun 1945 (UUD 1945). (Hidayat)

Pancasila berperan sebagai paradigma pembangunan hukum harus menjadi acuan dalam segala pemikiran, sikap dan tindakan serta kegiatan hukum yang dilakukan di negara Indonesia. Termasuk di bidang hukum 


\section{AL-QISTH LAW REVIEW \\ VOL 5 NO. 1 (2021)}

tentu harus berpedoman terhadap Pancasila, agar hukum yang dihasilkan sesuai dengan prinsip nilainilai Pancasila. Sebagai sumber dari segala sumber hukum, maka Pancasila sebagai grundnorm bagi setiap peraturan perundangundangan yang memiliki posisi di bawah Pancasila. Sehingga harus mendasarkan rasio logisnya pada Pancasila dan tidak boleh bertentangan dengannya. Penerapan nilai-nilai filsafat hukum Pancasila menjadi penting pada setiap peraturan perundang-undangan di Indonesia. Material filsafat hukum Pancasila digali dari nilai-nilai luhur bangsa Indonesia yang telah ada sejak ribuan tahun yang lalu. filsafat hukum Pancasila dengan demikian lahir dari perasaan dan pengetahuan bangsa Indonesia atas diri dan lingkungannya. (Nugroho: 2010)

\section{b. Membangun Pembaharuan Hukum Pidana Nasional Di Atas Pondasi Keadilan Pancasila Dalam Wujud Nilai Ketuhanan Yang Maha Esa.}

Persoalan keadilan dalam penegakan hukum selalu menjadi yang diperdebatkan dalam masyarakat, hal ini dikarenakan adanya ketidakpercayaan masyarakat terhadap penegakan hukum. Jelasnya menurut Barda Nawawi Arief bahwa, betapa kacau dan tidak tenteramnya kehidupan masyarakat apabila masyarakat tidak lagi mempercayakan penyelesaian masalah-masalah mereka pada penegak hukum.(Arief: 2005)

Bertitik tolak pada ketidak percayaan masyarakat bukan sematamata pada persoalan proses penegakan hukum, akan tetapi secara 


\section{1}

\section{AL-QISTH LAW REVIEW \\ VOL 5 NO. 1 (2021)}

substansi mempengaruhi dimana hukum materil yang menjadi dasar larangan pada suatu perbuatan itulah yang berdampak pada tidak adilnya hukum. Wajar kiranya apabila karakter hukum pidana kita masih dipertanyakan nilai keadilannya oleh masyarakat, karena ruh yang terkandung pada undang-undang pidana saat ini tidak sejalan dengan budaya masyarakat Indonesia yang berlandaskan Pancasila, karena pada dasarnya Kitab Undang-undang Hukum Pidana (KUHP) Wetboek van Strafrecht (WvS) merupakan peninggalan pemerintah zaman kolonial Belanda yang di dasarkan pada ajaran yang menonjolkan paham individualisme dan liberalisme.

Penerapan hukum yang telah usang dan ketinggalan jaman juga menjadi salah satu faktor kegagalan penegakan hukum di Indonesia, Lebih lanjut menurut P.A.F. Lamintang dan Djisman Samosir dalam sebuah bukunya (Lamintang dan Samosir: 1983) mengemukakan bahwa KUHP yang hingga kini dipergunakan oleh para penegak hukum, hampir semuanya merupakan KUHP yang “telah ketinggalan zaman”, sehingga di dalam penggunaannya bukan tidak mungkin akan dapat menjadi hambatan di dalam usaha mereka untuk menegakkan hukum dan bukan tidak mungkin pula, bahwa penggunaan KUHP yang telah ketinggalan zaman tersebut akan mengarah kepada penerapan hukum secara salah pula, yang pada akhirnya akan dapat menurunkan wibawa dari para penegak hukum itu sendiri. 


\section{AL-QISTH LAW REVIEW \\ VOL 5 NO. 1 (2021)}

Berdasarkan hal tersebut di atas maka upaya melakukan pembaharuan KUHP bukan hanya merupakan tuntutan nasional tapi juga merupakan kecenderungan Internasional. Pembaharuan Hukum Nasional. Menurut Barda Nawawi Arief "makna dan hakekat pembaharuan hukum pidana berkaitan erat dengan latar belakang dan urgensi diadakannya pembaharuan hukum pidana itu sendiri. Latar belakang dan urgensi diadakannya pembaharuan hukum pidana dapat ditinjau dari aspek sosiopolitik, sosiofilosofis, sosiokultural atau dari aspek kebijakan (khususnya kebijakan sosial, kebijakan kriminal dan kebijakan penegakan hukum). Ini berarti, makna dan hakekat pembaharuan hukum pidana juga berkaitan erat dengan"' (Arief: 2008)

Berdasarkan penjelasan di atas maka hemat penulis baiknya dalam rangka Pembangunan sistem hukum pidana nasional harus berakar dari nilai-nilai luhur Pancasila yang terkandung dalam Pancasila sehingga sesuai dengan jiwa bangsa (volkgeits). Hukum yang tumbuh dan berkembang dari masyarakat dengan mengintegrasikan nilai-nilai luhur di masyarakatnya, pada gilirannya akan mampu melahirkan hukum yang aspiratif dan akomodatif sesuai dengan kebiasaan masyarakat.

Esmi Warassih dalam pidato Pengukuhannya sebagai guru besar berpendapat bahwa penerapan suatu sistem hukum yang tidak berasal atau ditumbuhkan dari kandungan masyarakat merupakan masalah, khususnya di negara-negara yang sedang berubah karena terjadi ketidak cocokan antara nilai-nilai yang menjadi pendukung sistem hukum dari 


\section{AL-QISTH LAW REVIEW \\ VOL 5 NO. 1 (2021)}

negara lain dengan nilai-nilai yang dihayati oleh anggota masyarakat itu sendiri. (Pujirahayu: 2006)

Selanjutnya ditegaskan oleh Barda Nawawi Arief Pengembangan Ilmu Hukum Nasional terkait erat dengan pengertian dan hakikat "ilmu hukum" yang merupakan "normatieve maatschappij wetenschap", yaitu "ilmu normatif tentang hubungan kemasyarakatan" atau "ilmu hubungan kemasyarakatan (kenyataan) yang normatif" sehingga ilmu hukum merupakan "ilmu normatif (das Sollen) tentang kenyataan (das Sein"), atau “ilmu kenyataan (das Sein) yang normatif". (Arief: 2009)

Lebih lanjut Barda Nawawi Arief, menyatakan bahwa, jika sekiranya yang dicita-citakan Sistem Hukum Nasional adalah Sistem Hukum Pancasila, maka sepatutnya dikaji dan dikembangkan Sistem Hukum Pidana (yang mengandung nilai-nilai Pancasila), yaitu hukum pidana yang berorientasi pada nilai-nilai "Ketuhanan YME", hukum pidana yang ber-"Kemanusiaan yang adil dan beradab", hukum pidana yang mengandung nilai-nilai "persatuan" (antara lain: tidak membedakan suku/ golongan/agama, mendahulukan kepentingan bersama), hukum pidana yang dijiwai nilai-nilai "kerakyatan yang dipimpin hikmah kebijaksanaan dalam permusyawaratan" (antara lain mengutamakan kepentingan/kesejahteraan rakyat, penyelesaian konflik secara bijaksana/ musyawarah/kekeluargaan), dan hukum pidana yang ber-"keadilan sosial". Inilah masalah besar yang menantang dan belum dituntaskan. (Arief: 1994) 


\section{AL-QISTH LAW REVIEW \\ VOL 5 NO. 1 (2021)}

Tentang pembangunan hukum yang berkakrakter pancasila, selanjutnya ditegaskan Arief Hidayat (Hidayat: MK RI) yang menyatakan bahwa karakteristik dari negara hukum Pancasila adalah sebagai berikut:

Pertama, merupakan suatu negara kekeluargaan. Dalam suatu negara kekeluargaan terdapat pengakuan terhadap hak-hak individu (termasuk pula hak milik) atau HAM namun dengan tetap mengutamakan kepentingan nasional (kepentingan bersama) diatas kepentingan individu tersebut. Hal ini di satu sisi sejalan dengan nilai sosial masyarakat Indonesia yang bersifat paguyuban, namun disisi lain juga sejalan pergeseran masyarakat Indonesia ke arah masyarakat modern yang bersifat patembayan. Hal ini sungguh jauh bertolak belakang dengan konsep negara hukum barat yang menekankan pada kebebasan individu seluasluasnya, sekaligus bertolak belakang dengan konsep negara hukum sosialisme-komunisme yang menekankan pada kepentingan komunal atau bersama. Dalam negara hukum Pancasila, diusahakan terciptanya suatu harmoni dan keseimbangan antara kepentingan individu dan kepentingan nasional (masyarakat) dengan memberikan pada negara kemungkinan untuk melakukan campur tangan sepanjang diperlukan bagi terciptanya tata kehidupan berbangsa dan bernegara yang sesuai dengan prinsip-prinsip Pancasila.

Kedua, merupakan negara hukum yang berkepastian dan berkeadilan. Dengan sifatnya yang prismatik maka konsep negara hukum Pancasila dalam kegiatan berhukum baik dalam proses pembentukan maupun pengimplementasiannya dilakukan dengan memadukan berbagai unsur yang baik yang terkandung dalam konsep Rechtsstaat maupunthe Rule of Law yakni dengan memadukan antara prinsip kepastian hukum dengan prinsip keadilan,serta konsep dan sistem hukum lain, misalnya sistem hukum adat dan sistem hukum agama yang hidup di nusantara ini, sehingga terciptalah suatu prasyarat bahwa kepastian hukum harus ditegakkan demi menegakkan keadilan dalam masyarakat sesuai dengan prinsip-prinsip Pancasila. 


\section{AL-QISTH LAW REVIEW \\ VOL 5 NO. 1 (2021)}

Ketiga, merupakan religious nation state. Dengan melihat pada hubungan antara negara dan agama maka konsep negara hukum Pancasila tidaklah menganut sekulerisme tetapi juga bukanlah sebuah negara agama seperti dalam teokrasi dan dalam konsep Nomokrasi Islam. Konsep negara hukum Pancasila yang adalah sebuah konsep negara yang berketuhanan. Berketuhanan adalah dalam arti bahwa kehidupan berbangsa dan bernegara Indonesia didasarkan atas kepercayaan kepada Ketuhanan Yang Maha Esa, dengan begitu maka terbukalah suatu kebebasan bagi warga negara untuk memeluk agama dan kepercayaan sesuai keyakinan masing-masing. Konsekuensi logis dari pilihan prismatik ini adalah bahwa atheisme dan juga komunisme dilarang karena telah mengesampingkan kepercayaan terhadap Tuhan Yang Maha Esa.

Keempat, memadukan hukum sebagai sarana perubahan masyarakat dan hukum sebagai cermin budaya masyarakat. Dengan memadukan kedua konsep ini negara hukum Pancasila mencoba untuk memelihara dan mencerminkan nilai-nilai yang hidup dalam masyarakat (living law) sekaligus pula melakukan positivisasi terhadap living law tersebut untuk mendorong dan mengarahkan masyarakat pada perkembangan dan kemajuan yang sesuai dengan prinsip-prinsip Pancasila. Saya kurang setuju dengan berlakunya prinsip pluralisme/multikulturalisme diterapkan di Indonesia. Pandangan Saya semestinya di Indonesia menganut asas/prinsip Bhinneka Tunggal Ika dalam membangun sistem hukum nasional. Sehingga meskipun kita perlu menganut prinsip unifikasi hukum, namun unifikasi hukum yang kita anut dan kita bangun mestilah memperhatikan sisi-sisi universal dari setiap perbedaan sebagaimana prinsip Bhinneka Tunggal Ika.

Kelima, basis pembuatan dan pembentukan hukum nasional haruslah didasarkan pada prinsip hukum yang bersifat netral dan universal, dalam pengertian bahwa harus memenuhi persyaratan utama yaitu Pancasila sebagai perekat dan pemersatu; berlandaskan nilai yang dapat diterima oleh semua kepentingan dan tidak mengistimewakan kelompok atau golongan tertentu; mengutamakan 


\section{6}

\section{AL-QISTH LAW REVIEW \\ VOL 5 NO. 1 (2021)}

prinsip gotong royong dan toleransi; serta adanya kesamaan visi-misi, tujuan dan orientasi yang sama disertai dengan saling percaya.

Kaitannya dengan pembangunan hukum pidana nasional yang didasarkan pada pondasi pancasila dengan nilai keadilan tuhan penulis kutif dari Kesimpulan Seminar Hukum Nasional ke VI (1994) pernah menegaskan, bahwa perlu untuk dikembangkan gagasan mengenai kualitas pemberian keadilan (the dispension of justice) yang cocok dengan sistem hukum Pancasila. (Fatoni: 2015). Bahkan Paul Scholten mengatakan bahwa Ilmu Hukum adalah juga “ilmu tentang keadilan”? (Scholten: 2003). Jika cita-cita Pembaharuan hukum pidana nasional dihendaki pada nilai Pancasila, maka keadilan hukum idealnya harus dijiwai nilai Ketuhanan yang Maha Esa.

Keadilan berdasarkan ketuhanan yang dimaksud diatas menurut Barda Nawai Arief “bahwa keadilan berdasarkan Ketuhanan Yang Maha Esa berarti keadilan berdasarkan tuntunan Tuhan yang mengandung prinsip-prinsip: (1) persamaan; (2) objektivitas; (3) tidak pilih kasih; dan (4) tidak berpihak." (Arief: 2011)

Filsafat Pancasila tergolong filsafat yang religius, artinya bahwa filsafat Pancasila dalam hal kebijaksanaan dan kebenaran mengenal adanya kebenaran mutlak yang berasal dari Tuhan Yang Maha Esa (kebenaran religius) sekaligus mengakui keterbatasan kemampuan manusia, termasuk kemampunan berpikirnya. Adapun Ketuhanan Yang Maha Esa 


\section{AL-QISTH LAW REVIEW \\ VOL 5 NO. 1 (2021)}

mengandung pengertian dan keyakinan adanya Tuhan Yang Maha Esa, pencipta alam semesta beserta isinya. (Kaelan dan Zubaidi: 2007)

Lebih lanjut menurut Burhanuddin Salam Sila Ketuhanan Yang Maha Esa mengandung pengertian dan keyakinan adanya Tuhan Yang Maha Esa, Pencipta alam semesta beserta isinya. Keyakinan ini bukanlah suatu dogma (kepercayaan yang tidak dapat dibuktikan kebenaran nya melalui akal pikiran) melainkan sesuatu kepercayaan yang berakar pada pengetahuan yang benar, yang dapat diuji (dibuktikan) melalui kaidahkaidah logika. Ketuhanan Yang Maha Esa menjadi sumber pokok nilai kehidupan bangsa Indonesia, menjiwai dan mendasari serta membimbing perwujudan kemanusiaan yang adil dan beradab, menggalang persatuan Indonesia yang telah mencipta kan Negara Republik Indonesia yang berdaulat penuh, yang bersifat kerakyatan yang dipimpin oleh hikmat kebijaksanaan dalam permusyawaratan/perwakilan, guna mewujudkan keadilan sosial bagi seluruh rakyat Indonesia. (Salam: 1987)

Pemaknaan tentang nilai Ketuhanan yang Maha Esa dalam kerangka pancasila, Arief Hidayat memaknai bahwa: religious nation state. Dengan melihat pada hubungan antara negara dan agama maka konsep negara hukum Pancasila tidaklah menganut sekulerisme tetapi juga bukanlah sebuah negara agama seperti dalam teokrasi dan dalam konsep Nomokrasi Islam. Konsep negara hukum Pancasila yang adalah sebuah konsep negara yang berketuhanan. Berketuhanan adalah dalam arti bahwa kehidupan berbangsa dan bernegara Indonesia didasarkan atas 


\section{AL-QISTH LAW REVIEW \\ VOL 5 NO. 1 (2021)}

kepercayaan kepada Ketuhanan Yang Maha Esa, dengan begitu maka terbukalah suatu kebebasan bagi warga negara untuk memeluk agama dan kepercayaan sesuai keyakinan masing-masing. Konsekuensi logis dari pilihan prismatik ini adalah bahwa atheisme dan juga komunisme dilarang karena telah mengesampingkan kepercayaan terhadap Tuhan Yang Maha Esa.

Adapun nilai-nilai yang terkandung dalam Sila Ketuhanan Yang Maha Esa adalah bahwa negara yang didirikan adalah sebagai pengejawantahan tujuan manusia sebagai makhluk Tuhan Yang Maha Esa. Oleh karena itu segala hal yang berkaitan dengan pelaksanaan dan penyelenggaraan negara bahkan moral negara, moral penyelenggara negara, pemerintahan negara, hukum dan peraturan perundang-undangan negara, kebebasan dan hak asasi warga negara harus dijiwai nilai-nilai Ketuhanan Yang Maha Esa.(Kaelan dan Zubaidi: 2007)

Istiah Ketuhanan menurut Kaelan dan Achmad Zubaidi berasal dari pokok kata Tuhan, yaitu suatu Dzat Yang Maha Kuasa pencipta segala yang ada di alam semesta ini, yang biasa disebut Penyebab Pertama atau Kausa Prima. Sedang istilah Ketuhanan berarti keyakinan dan pengakuan yang diekspresikan dalam bentuk perbuatan terhadap Dzat Yang Maha Kuasa sebagai Pencipta, Yang Maha Esa berarti yang Maha Tunggal, tiada tersusun, tiada duanya, tunggal dalam dzat-Nya, tunggal dalam sifatNya dan tunggal dalam perbuatan-Nya. (Bakry: 1990). Berdasarkan hal di atas maka yang dimaksud dengan Ketuhanan Yang Maha Esa adalah: 


\section{AL-QISTH LAW REVIEW \\ VOL 5 NO. 1 (2021)}

Keyakinan dan pengakuan yang diwujudkan dalam bentuk perbuatan terhadap suatu dzat Yang Maha Tunggal tiada duanya, yang Sempurna sebagai Penyebab Pertama. (Bakry: 1990)

Sebagaimana yang telah diuraikan di atas maka masalah sentral dari sudut kebijakan hukum pidana dalam rangka pembaharuan hukum nasional sebenarnya terletak pada masalah konsep nilai (pandangan/ideologi) hubungan kekuasaan/hak antara negara dan warga masyarakat, karenanya upaya melakukan pembaharuan hukum pidana pada hakikatnya termasuk bidang yang merupakan bagian dan terkait erat dengan pembaharuan Sistem Hukum Nasional, yang berorientasi pada nilai Pancasila.

Berdasarkan pendapat di atas dipandang dari sudut pendekatan nilai maka tidak dapat dikatakan melakukan pembaruan jika pokok-pokok pemikiran, ide-ide dasar dan nilai-nilai sosiofilosofi, sosio-politik, dan sosio-kultural yang melandasi KUHP masih sama dengan KUHP lama $(\mathrm{WvS})$, sehingga perlu dilakukan re-orientasi dan reevaluasi terhadap nilainilai filosofi yang melatarbelakangi dan melandasi KUHP (WvS) yang tidak sesuai dengan nilainilai filosofi bangsa antara lain nilai-nilai Ketuhanan YME. 


\section{AL-QISTH LAW REVIEW \\ VOL 5 NO. 1 (2021)}

\section{KESIMPULAN}

Dari latarbelakang KUHP saat ini yang sudah sangat tertinggal jauh serta melekatnya pemikiran politik hukum yang liberal dan individualisme, untuk itu penggunaan KUHP sudah tidak cocok dengan karakter kultur masyarakat bangsa Indonesia. Untuk itu Pancasila sebagai nilai-nilai kehidupan berbangsa dan bernegara yang dicitacitakan, karenanya pembaharuan hukum pidana pada hakekatnya mengandung makna, suatu upaya untuk melakukan reorientasi dan reformasi hukum pidana yang sesuai dengan nilai-nilai sentral sosio-politik, sosio-filosofis, dan sosiokultural masyarakat Indonesia yang melandasi kebijakan sosial, kebijakan kriminal dan kebijakan penegakan hukum di Indonesia. Hal ini berarti pembaharuan KUHP seyogyanya dilatarbelakangi dan bersumber pada nilai-nilai Pancasila. Nilai yang terkandung dalam Sila Ketuhanan Yang Maha Esa merupakan pemikiran dasar dalam upaya pembangunan hukum pidana nasional dengan demikian perlu dilakukan penggalian terhadap nilai-nilai hukum agama untuk diintegrasikan dalam pembangunan sistem hukum nasional, karena pada dasarnya Hukum pidana adalah hukum yang ultimum remidium/ sebagai upaya terakhir, yang berarti hukum pidana adalah hukum yang memiliki kadar sanksi yang paling berat dibanding hukum yang lainnya. Karenanya sangat penting sekali hukum pidana dibangun dilandaskan pada pondasi nilai pancasila khususnya pada nilai ketuhanan, agar selanjutnya dalam penegakan hukum pidana memiliki banyak pertimbangan moral dan tidak identik dengan kekejaman. 


\section{AL-QISTH LAW REVIEW}

VOL 5 NO. 1 (2021)

\section{DAFTAR PUSTAKA.}

Arief, B. N. (2008). Bunga Rampai Kebijakan Hukum Pidana (Perkembangan Penyusunan Konsep KUHP Baru), Jakarta: Kencana Prenada Media Group.

Arief, B. N. (1994). Menyongsong Generasi Hukum Pidana Indonesia. Semarang: Pidato Pengukuhan Guru Besar di FH Undip.

Arief, B. N. (2009). Pembangunan Sistem Hukum Nasional Indonesia. Materi Kuliah Umum pada Program Magister Ilmu Hukum. Padang: Pascasarjana UBH.

Arief, B. N. (2005). Beberapa Aspek Kebijakan Penegakan dan Pengembangan Hukum Pidana, Bandung: Penerbit Citra Aditya Bakti.

Arief, B. N. (2011). Pendekatan Keilmuan dan Pendekatan Religius Dalam Rangka Optimalisasi dan Refomasi Penegakan Hukum (Pidana) di Indonesia. Semarang: Badan Penerbit Undip.

Assihiddiqie. J. (2006). Pengantar Ilmu Tata Negara. Jakarta: Sekretariat Jenderal dan Kesekretariatan Mahkamah Konstitusi RI.

Bakhry, MS. N. (1990). Orientasi Filsafat Pancasila. Yogyakarta: Liberty. 


\section{AL-QISTH LAW REVIEW \\ VOL 5 NO. 1 (2021)}

Fatoni, S. (2015). Pembaruan Hukum Pidana , AHKAM, Volume 3, Nomor 1, Juli.

Hidayat, A. Negara Hukum Berwatak Pancasila, Jakarta: Mahkamah Konstitusi RI.

Hidayat, A. Bernegara Itu Tidak Mudah (Dalam Prespektif Politik dan Hukum), Pengukuhan Guru Besar Undip.

Kaelan dan Zubaidi, A. (2007). Pendidikan Kewarganegaraan Untuk Perguruan Tinggi Berdasar SK Dirjrn Dikti No.43/DIKTI/ KEP/2006. Yogyakarta: Paradigma.

Latif. Y. (2012). Negara Paripurna, Historisitas, Rasionalitas Dan Aktualitas Pancasila. Jakarta: Pustaka Utama.

Lamintang, P.A.F. dan Samosir, D. (1983). Hukum Pidana Indonesia. Bandung: Sinar Baru.

Nugroho, S. S. (2016). Membumikan Hukum Pancasila Sebagai Basis Hukum Nasional Masa Depan (Cita Hukum Pancasila). Solo: Iltizam.

Nugroho, I. (2010) Nilai-Nilai Pancasila Sebagai Falsafah Pandangan Hidup Bangsa Untuk Peningkatan Kualitas Sumber Daya Manusia Dan Pembangunan Lingkungan Hidup. Jurnal Konstitusi ISSN 1829-7706.

Pujirahayu, E. W. (2006). Menggagas Hukum Progresif Indonesia. Semarang: Pustaka Pelajar. 


\section{3 \\ AL-QISTH LAW REVIEW \\ VOL 5 NO. 1 (2021)}

Rahardjo, S. Hukum Kita Liberal (Apa Yang Dapat Kita Lakukan) Kompas 3 Januari 2001.

Salam, B. (1987). Filsafat Pancasilaisme. Jakarta: Rineka Cipta.

Sidharta, A. (2003). Struktur Ilmu Hukum. Bandung: Penerbit Alumni.

Sudjito. (2014). Pancasila Sebagai Dasar Filsafat Dan Paradigma Ilmu Hukum, materi Kuliah Umum Sekolah Pasca Sarjana UMS, 29 November 2014.

Wahyuningsih, S. E. (2014). Urgensi Pembaharuan Hukum Pidana Materiel Indonesia Berdasarkan Nilai-Nilai Ketuhanan Yang Maha Esa, Jurnal Pembaharuan Hukum Volume I No.1 Januari -April. 